\title{
EMERGENCY CONDITIONS IN SURGERY
}

\author{
Bobana Milojković1, Dragan Mihajlović1, Marija Dimitrijević2 , Boban Milojkovićc \\ Jelena Ignjatovićs
}

\begin{abstract}
All acute conditions in surgery are clinically presented as acute abdomen. The aim of this study was to identify the most common causes of emergency conditions in surgery.

We included 165 patients operated in the Emergency Centre, Clinical Center Niš for intra-abdominal perforation with a final diagnosis of diffuse peritonitis and bleeding. There were $92(56 \%)$ women and $73(44 \%)$ men.

Appendicular perforation was the cause of peritonitis in $29(27.9 \%)$ patients, gastric perforation in $24(23.1 \%)$ patients, jejunum perforation in $5(4.8 \%)$ patients, and ileum perforation in $7(6.7 \%)$ patients. Large bowel perforation was the cause of peritonitis in 20 $(19.2 \%)$ patients, rectum perforation in $6(5.8 \%)$ patients and perforation of gall bladder in 13 $(12.5 \%)$ patients. Gastric ulcer bleeding was found in $24(39.3 \%)$ patients, duodenal ulcer in $18(29.5 \%)$ patients, $11(18.1 \%)$ patients had splenic injury and bleeding, in $5(8.2 \%)$ patients liver bleeding occurred, and in $3(4.9 \%)$ patients, the bleeding was caused by esophageal varices. The overall mortality was $20.6 \%(n=34)$. Due to the consequences of septic condition (SC) $14(41.2 \%)$ patients died, and $20(58.8 \%)$ died of complications of gastrointestinal bleeding (GIB).
\end{abstract}

The morbidity and mortality rates of emergency conditions are still unacceptably high. Acta Medica Medianae 2020;59(2):66-71.

Key words: acute abdomen, peritonitis, bleeding

${ }^{1}$ Clinic of Digestive Surgery, Clinical Center Niš, Niš, Serbia

${ }^{2}$ Emergency Center, Clinical Center Niš, Niš, Serbia

${ }^{3}$ University of Niš, Faculty of Medicine, Niš, Serbia

Contact: Bobana Milojković

48 Dr Zoran Djindjić Blvd., 18000 Niš, Serbia

E-mail: bobana.milojkovic@medfak.ni.ac.rs

\section{Introduction}

All acute conditions in surgery are clinically presented as acute abdomen. Acute abdomen includes all abdominal conditions and diseases that require immediate surgical intervention.

Differential diagnostics should pay attention to the conditions that resemble an acute abdomen and they are not as well as pseudo-acute abdomen. It is most often acute pancreatitis, abdominal angina or a consequence of electrolyte disturbances (1). Timely and correct diagnosis is crucial, which includes a detailed anamnesis, clinical examination and appropriate diagnostic procedures. Timely diagnosis is the key to successful treatment (1).
Acute generalised peritonitis is an urgent condition and is known as one of the leading causes of death in non-traumatized patients despite advances in diagnosis and surgical treatment with mortality rate ranging from 10 to $32 \%(1,2)$.

It is well known that generalised peritonitis is the most important surgical condition in general surgical practice. The most common cause is perforation in the gastrointestinal tract.

The abdomen seems to be Pandora's Box because the surprises are the rule rather than the exception. The most important signs to make the adequate diagnosis are diffuse pain and rigidity of the abdomen with the presence of pneumoperitoneum on X-ray of the abdomen, which means gas under diaphragm $(1,3)$.

Pain is the main reason that brings patients to the Emergency Center. Visceral pain is usually diffuse and not easy for localizing. Somatic pain is usually well localized, intermittent or constant and described as aching, gnawing and throbbing $(1,2)$. Acute gastrointestinal bleeding due to the dramatic clinical picture and the need for urgent therapeutic and diagnostic procedures have priority in hospital treatment and represents the reason for $1.5 \%$ of all emergency hospitalizations today.

The most important thing for emergency conditions is making an accurate diagnosis trough the clinical examination, good history and adequate 
diagnostic investigation (1). Acute abdomen is a condition that must be treated by many specialists (4).

\section{The aim}

The aim of this study was to identify the most common causes in emergency conditions in surgery.

\section{Material and method}

The study included 165 patients operated in the Emergency centre - Clinical Center Niš from 2017. to 2019 for an intra-abdominal perforation with a final diagnosis of diffuse peritonitis and patients operated for bleeding. Diffuse peritonitis is defined as any intra-abdominal infection that extends beyond the transverse mesocolon (2).

\section{Results}

The study involved 165 patients operated on for acute abdomen. There were 92 (56\%) women and 73 (44\%) men (Figure 1).

Appendicular perforation was the cause of peritonitis in 29 (27.9\%) patients, gastric perforation in $24(23.1 \%)$ patients, jejunum perforation in 5 $(4.8 \%)$ patients, and ileum perforation in $7(6.7 \%)$ patients. Large bowel perforation was the cause of peritonitis in $20(19.2 \%)$ patients, rectum perforation in $6(5.8 \%)$ patients and perforation of gall bladder in $13(12.5 \%)$ patients (Table 1$)$.

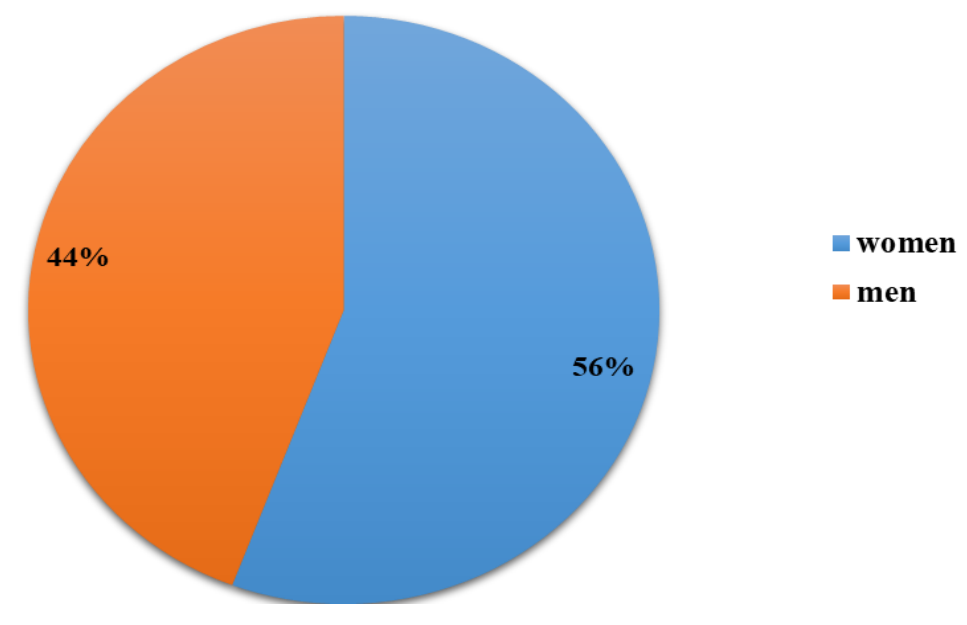

Figure 1. Distribution of patients operated of acute abdomen in relation to gender

Table 1. Distribution by causes of peritonitis

\begin{tabular}{|l||c|c||}
\hline Causes of peritonitis & $\mathrm{n}$ & $\mathrm{n}(\%)$ \\
\hline \hline Appendicular perforation & 29 & 27.9 \\
Gastric perforation & 24 & 23.1 \\
Jejunum perforation & 5 & 4.8 \\
Ileum perforation & 7 & 6.7 \\
Bowel perforation & 20 & 19.2 \\
Rectum perforation & 6 & 5.8 \\
Perforation of gall bladder & 13 & 12.5 \\
\hline
\end{tabular}

The cause of acute abdomen was perforation in $104(63 \%)$ patients and in $61(37 \%)$ it was intraabdominal bleeding (Figure 2).

Gastric ulcer bleeding was found in 24 (39.3\%) patients, duodenal ulcer in 18 (29.5\%) pa- tients, $11(18.1 \%)$ patients had splenic injury and bleeding, in $5(8.2 \%)$ patients liver bleeding occurred, and in $3(4.9 \%)$ patients, the bleeding was caused by esophageal varices (Table 2 ). 
The overall mortality was $20.6 \%(n=34)$. Due to the consequences of septic condition (SC), $14(41.2 \%)$ patients died and $20(58.8 \%)$ patients died of complications of gastrointestinal bleeding (GIB) (Figure 3).

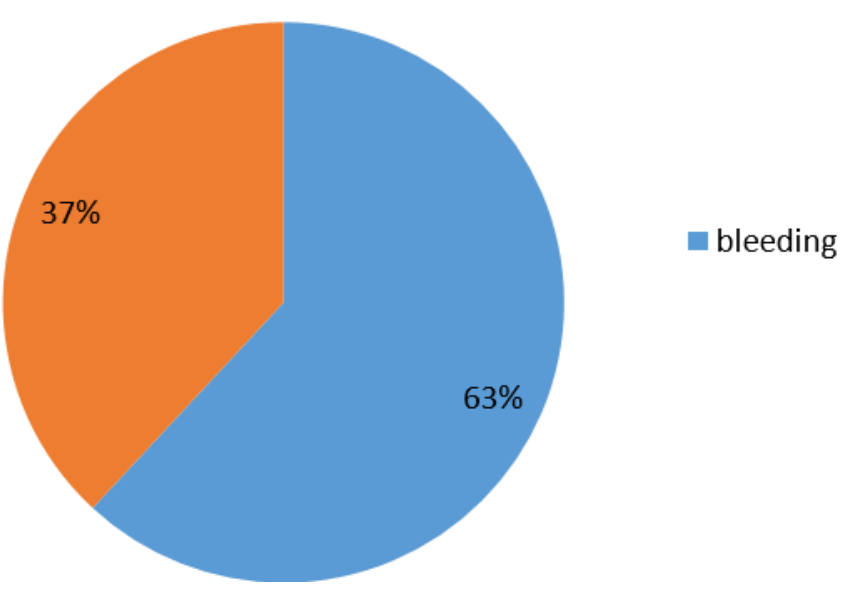

Figure 2. Distribution by causes of emergency condition

Table 2. Distribution by causes of intra-abdominal bleeding

\begin{tabular}{|l||c|c||}
\hline Causes of intra-abdominal bleeding & $\mathrm{n} \mathrm{( \% )}$ & $\mathrm{n} \mathrm{( \% )}$ \\
\hline \hline Bleeding gastric ulcer & 24 & 39.3 \\
\hline Duodenal ulcer & 18 & 29.5 \\
\hline Splenic injury and bleeding & 11 & 18.1 \\
\hline Liver bleeding & 5 & 8.2 \\
\hline Esophageal varices & 3 & 4.9 \\
\hline
\end{tabular}

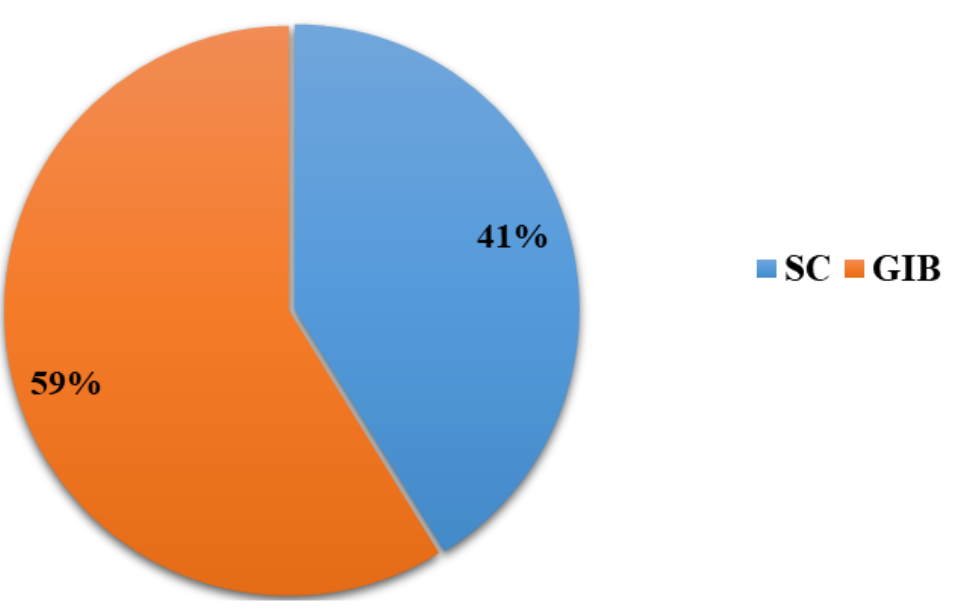

Figure 3.The overall mortality of patients 


\section{Discussion}

Acute abdomen is a syndrome that occurs as a consequence of a pathological process in the intraabdominal organs and leads to deadly complications as it progresses. It can be caused by illness or trauma and requires a rapid response. Abdominal pain can be confused with extra abdominal and thoracic conditions such as acute myocardial infarction and pneumonia $(4,5,6)$.

Peritonitis can be defined in several ways.

Primary peritonitis is an infection of the peritoneal cavity that occurs in patients with ascites fluid and who do not have other intra-abdominal diseases or are not associated with them. The most common and most dangerous form of peritonitis is secondary peritonitis. It occurs due to spontaneous perforation of intra-abdominal organs, intestinal ischemia or after operations. Tertiary peritonitis is a recurrent infection in the abdomen occurring in patients after primary or secondary peritonitis (6). Sudden and sharp abdominal pain is the most significant sign of an acute abdomen. It takes necessary knowledge and skills to make a correct diagnosis. The localization of pain is important in determining various diagnoses, but sometimes the pain can also be projected or moved, which often leads to an error (5).

The localization of pain in the upper right quadrant is specific for acute cholecystitis or liver diseases. Pain in the epigastrium, then in the lower right quadrant, followed by fever and vomiting, indicates acute appendicitis. The existence of a gynecological or urological disease should also be ruled out. Ulcer disease is localized in the epigastrium or in the lower abdomen. It can occur before or after a meal, which determines whether it originates from the stomach or duodenum. Renal colic is accompanied by pain that is projected towards the genitals. The duration of the pain also determines the type of disease, whether the pain is short-lived and strong or lasts. The pain that occurs with perforations intensifies over time and spreads to the entire abdomen $(4,6,11)$.

Colic is connected with many diseases of abdomen and it is the first sign. The pathophysiology of pain is thought to be smooth muscle contraction proximal to a partial or complete obstruction. The localization of colic usually helps to diagnose and find the reason of pain. The absence of colic can be found in several diseases, but rarely.

In case a patient experiences abdominal pain, fever, vomiting, fainting, or signs of blood loss, acute surgical disease should be suspected. A high mortality and morbidity rate has been observed in cases of acute abdomen in which there are other associated diseases.

Conditions in patients with abdominal pain that are suggestive of surgical or emergent conditions are fever, protracted vomiting, syncope or presyncope, and signs of gastrointestinal blood loss (5).
The mortality and morbidity rates are very high when the patient happens to have an associated disease in addition to the acute abdomen.

Acute abdomen resulting from intestinal ischemia and necrosis has a poor prognosis $(4,6)$.

One of the most common causes of acute abdomen is acute appendicitis that requires emergency surgery to reduce postoperative complications, and directly affects the reduction of mortality, which is approximately $1 \%$ in these patients $(7,12)$. Making a timely diagnosis is the most important thing in this condition.

In mechanical or paralytic ileus, ischemic necrosis of the intestinal wall occurs with bacteria penetrating the abdominal cavity causing peritonitis. Rupture of hollow organs such as perforation of gastroduodenal ulcer, rupture of colon cancer, inflamed diverticulum can cause peritonitis. These complications lead to secondary peritonitis where the primary pathological process is located in the abdomen itself.

The operation is urgent, when the abscess is evacuated, the damaged part of the intestine is resected, and a protective colostomy is performed. On rare occasions, an anastomosis is performed in the first act, due to the greater possibility of dehiscence of the anastomosis postoperatively (8).

A number of patients with perforations due to gastric cancer are usually treated by resective procedures. Jejunoileal perforations are not often common as a cause of peritonitis. Small intestinal perforations can be caused by intestinal necrosis or some trauma. Bleeding from the upper parts of the digestive system is one of the most common emergencies.

The incidence of infections after elective operations on the gastrointestinal tract ranges approximately $20-25 \%$ of patients with peritonitis $(9,10$, 13).

To summarize, the conditions that require emergency operations generally are associated with increased morbidity and mortality, especially in old people $(9,10)$. As far as the mortality in our study is concerned, it is similar to the rates in the majority of published reports.

\section{Conclusion}

All the previous facts suggest that diffuse peritonitis and bleeding are the most common and most dangerous conditions in surgery. A good clinical assessment is still crucial for the diagnosis.

It is especially important to pay attention to peritonitis caused by organ perforation. Beyond any doubt, the morbidity and mortality rates of emergency conditions are still very high and it is necessary to make the right diagnosis in time and do adequate surgery as soon as possible in order to improve the outcome. 


\section{References}

1. Smith J, Lobo D. Investigation of the acute Abdomen. Surgery 2012;30:6. [CrossRef]

2. Chichom-Mefire A, Alain Fon T, Ngowe M, ChichomMefire A. Which cause of diffuse peritonitis is the deadliest in the tropics? A retrospective analysis of 305 cases from the South-West Region of Cameroon. World Journal of Emergency Surgery (2016) 11:14. [CrossRef] [PubMed]

3. Desai A, Palande B, Dhabolkar S, Pai VD. Perforative Peritonitis-Gastrointestinal Tract May Not Always Be the Source. Indian J Surg 2017;79(2):160-2.

[CrossRef] [PubMed]

4. Mayumi T, Yoshida M, Tazuma S. Practice Guidelines for Primary Care of Acute Abdomen 2015. J Hepatobiliary Pancreat Sci 2016;23:3-36.

[CrossRef] [PubMed]

5. Cartwright $S$, Knudson $M$. Evaluation of Acute Abdominal Pain in Adults.

Available from URL: www.aafp.org/afp. [PubMed]

6. Mayumi T, Yoshida M, Tazuma S. J Hepatobiliary Pancreat Sci 2016;23:3-36. [CrossRef] [PubMed]

7. Merlino JI, Malangoni MA, Smith CM, Lange RL. Prospective randomized trials affect the outcomes of intraabdominal infection. Ann Surg 2001;233:859-66. [CrossRef] [PubMed]

8. Howe HJ, Casali RE, Westbrook KC, Thompson BW. Acute perforations of the sigmoid colon secondary to diverticulitis. Am J Surg 1979;137:184-7. [CrossRef]

9. Malangoni M, Inui T. Peritonitis - the Western experience. World Journal of Emergency Surgery 2006; $1: 25$. [CrossRef] [PubMed]

10. Linn BS, Linn MW, Wallen N. Evaluation of results of surgical procedures in the elderly. Ann Surg 1982; 195(1):90-6. [CrossRef] [PubMed]

11. Jhobta R, Attri A, Kaushik R, Sharma R, Jhobta A. Spectrum of perforation peritonitis in India-review of 504 consecutive cases. World Journal of Emergency Surgery 2006;1:26. [CrossRef] [PubMed]

12. Gupta S, Kaushik R. Peritonitis - the Eastern experience. World Journal of Emergency Surgery 2006;1:13. [CrossRef] [PubMed]

13. Navadgi S, Pandanaboyana S, John AW. Surgery for Acute Pancreatitis. Indian J Surg 2015;77:(5);446-52. [CrossRef] [PubMed] 


\title{
Originalni rad
}

UDC: 617.55-005.1

doi:10.5633/amm.2020.0209

\section{URGENTNA STANJA U HIRURGIJI}

\author{
Bobana Milojković1 , Dragan Mihajlović1, Marija Dimitrijević2, Boban Milojkovićc \\ Jelena Ignjatović3
}

\author{
${ }^{1}$ Klinika za digestivnu hirurgiju, Klinički centar Niš, Niš, Srbija \\ ${ }^{2}$ Urgentni centar, Klinički centar Niš, Niš, Srbija \\ 3Univerzitet u Nušu, Medicinski fakultet, Niš, Srbija \\ Kontakt: Bobana Milojković \\ Bulevar dr Zorana Đinđića 48, 18000 Niš, Srbija \\ E-mail: bobana.milojkovic@medfak.ni.ac.rs
}

Sva akutna stanja u hirurgiji klinički se prezentuju kao akutni abdomen. Cilj ove studije je identifikovanje najčešćih uzroka hitnih hirurških stanja.

Uključeno je 165 bolesnika operisanih zbog intraabdominalne perforacije, čija je konačna dijagnoza bila peritonitis. Bolesnici su operisani zbog krvarenja, u Urgentnom centru Kliničkog centra Niš, od toga 92 (56\%) žene i 73 (44\%) muškarca.

Kod $29(27,9 \%)$ bolesnika uzrok peritonitisa je perforacija apendiksa, kod $24(23,1 \%)$ bolesnika perforacija želuca, kod $5(4,8 \%)$ perforacija jejunuma, kod $7(6,7 \%)$ perforacija ileuma. Kod $20(19,2 \%)$ bolesnika uzrok peritonitisa je perforacija debelog creva, kod 6 $(5,8 \%)$ perforacija rektuma i perforacija žučne kese kod $13(12,5 \%)$ bolesnika. Kod 24 $(39,3 \%)$ bolesnika utvrđeno je krvarenje želudačnog ulkusa, kod $18(29,5 \%)$ krvarenje iz duodenuma, $11(18,1 \%)$ bolesnika imalo je povredu i krvarenje slezine, kod $5(8,2 \%)$ bolesnika javilo se krvarenje jetre i kod $3(4,9 \%)$ bolesnika razlog krvarenja bili su varikoziteti jednjaka. Ukupna smrtnost bila je $20,6 \%(n=34)$. Od posledica septičkog stanja umrlo je 14 $(41,2 \%)$ bolesnika, a $20(58,8 \%)$ usled komplikacija gastrointestinalnog krvarenja.

Stope morbiditeta i smrtnosti u urgentnim stanjima još uvek su neprihvatljivo visoke.

Acta Medica Medianae 2020;59(2):66-71.

Ključne reči: akutni abdomen, peritonitis, krvarenje 